\title{
MAKNA NYALE DALAM UPACARA ADAT PASOLA SEBAGAI UPAYA PELESTARIAN BUDAYA DI SUMBA BARAT NUSA TENGGARA TIMUR
}

Wilhelmus Kuara Jangga Uma

Program Studi Pendidikan Sejarah, FKIP, Universitas PGRI Madiun wilhelmus.uma@gmail.com

\section{Dwi Handayani}

Program Studi Pendidikan Sejarah, FKIP, Universitas PGRI Madiun Dwihandayani187@yahoo.co.id

Yoga Satriya Nurgiri

Program Studi Pendidikan Sejarah, FKIP, Universitas PGRI Madiun Yogasatriya008@gmail.com

\begin{abstract}
Abstrak
Tujuan penelitian ini adalah untuk mengetahui makna tradisi Nyale dalam prosesi Upacara Pasola di Sumba Barat Nusa Tenggara Timur. Metode peneltian yang digunakan adalah kualitatif dengan pendekatan deskriptif analitik. Teknik analisis data melalui tahap reduksi data, analisis data, verifikasi data. Hasil penelitian adalah Pertama, makna upacara ini digunakan untuk penghormatan peninggalan leluhur dan eksistensinya masih bertahan. Prosesi upacara tidak lepas dari nilai religi dan kepercayaan asli orang Sumba yaitu marapu. Kedua, Syair adat dan upacara penyajian kepada roh halus berfungsi sebagai naluri manusia dalam kepercayaan dan ungkapan syukur kepada Tuhan YME. Perwujudannya dalam bentuk tradisi ritual Nyale yaitu mencari cacing laut dan Pasola sebagai permainan perang di atas kuda menggunakan lembing atau tombak. Peranan ritual Nyale dan adat Pasola di Sumba Barat dimaknai sebagai alat pemersatu masyarakat berupa persaudaraan dan ungkapan kegembiraan sejati menyambut hasil panen. Meskipun upacara Pasola dipenuhi ketakutan karena melukai lawan, tetapi upacara ini terus dilestarikan. Nyale dan Pasola berkaitan erat dengan nilai luhur dalam pelaksanaan prosesi dan kepercayaan masyarakat Sumba. Ketiga, tahapan upacara Nyale dan Pasola adalah a) penentuan waktu pencarian cacing laut mulai dari perkumpulan para rato, b) persiapan kelengkapan Pasola yaitu kayu lembing, kuda, kain adat, dan c). prosesi pelaksanaan Pasola.
\end{abstract}

Kata Kunci: Tradisi, Nyale, Pasola, Sumba Timur

\begin{abstract}
The purpose of this research is to know the meaning of Nyale tradition in Pasola Ceremony procession in West Sumba Nusa Tenggara Timur. The method of research used is qualitative with analytic descriptive approach. Data analysis techniques through data reduction phase, data analysis, data verification. The results of research is First, the meaning of this ceremony is used to honor the ancestral heritage and its existence still survive. Ceremonial procession can not be separated from the religious values and beliefs of the original Sumba people are marapu. Secondly, the customary verse and ceremony of presentation to the subtle spirit serves as the human instinct in trust and gratitude to God Almighty. Its manifestation in the form of Nyale ritual tradition is looking for sea worms and Pasola as a war game on horseback using spears or spears. The role of nyale ritual and Pasola custom in West Sumba is interpreted as a unifying tool of society in the form of brotherhood and expressions of true joy to welcome the harvest. Although Pasola's ceremony was filled with fear for injuring an opponent, but the ceremony continued to be preserved. Nyale and Pasola are closely related to the noble values in the procession and the Sumba community's trust. Third, the ceremonies of Nyale and Pasola are a). the timing of the search of marine worms ranging from rato associations, $b$ ). preparation of Pasola fittings ie javelin wood, horse, custom fabric, and c). Pasola's implementation procession
\end{abstract}

Keyword: Tradition, Nyale, Pasola, East Sumba 


\section{PENDAHULUAN}

Indonesia memiliki banyak suku bangsa dan kebudayaan yang berbedabeda. Hal ini menunjukkan bahwa setiap masyarakat mengembangkan kebudayaan sendiri yang menyebabkan kebudayaannya memiliki cirik khas dibandingkan dengan suku bangsa lain. Pengembangan kebudayaan tersebut diperoleh dari pengalaman hidup nenek moyang mereka dan diwariskan kepada generasi berikutnya secara turun temurun sehingga membentuk kebudayaan suku bangsa yang ada sekarang ini. Tujuannya tak lain adalah memperkuat pemahaman dinamika historiografi masa lampau yang dimiliki bangsa (Khoirul Huda, 2017: 137).

Pada konteks kebudayaan, kearifan lokal merupakan aset budaya yang harus dipertahankan, dikembangkan dan dilestarikan keberadaannya, mengingat aset tersebut menunjukkan peradaban kehidupan berbudaya suatu bangsa. Pengembangan dan pelestarian kearifan lokal diterapkan sejak dini mulai dari tingkatan nasional, wilayah, perkotaan, kawasan dan lingkungan hunian harus berbasis dan memanfaatkan budaya dan kearifan lokal. Basis budaya tersebut harus dilakukan secara cerdas dan dipilih sesuai dengan kebutuhan dan relevansinya. Beberapa strategi yang dapat dilakukan untuk meningkatkan daya tahan budaya lokal antara lain: pembangunan jati diri bangsa, pemahaman falsafah budaya, penerbitan peraturan daerah, dan pemanfaatan teknologi informasi (Safril Mubah, 2011 :307).

Pengembangan dan pelestarian kearifan lokal dalam peraturan perundangan sudah cukup lengkap. Namun implementasi peraturan perundangan yang ada perlu sinergi dalam perwujudannya di tingkat lokal. Permasalahan yang terjadi pada masyarakat Indonesia yang selama ini cenderung kurang mencintai budaya sendiri dan menyamarkan serta kurang bangga terhadap budayanya. Keanekaragaman kebudayaan yang berwujud kesenian asli daerah yang tersebar di pelosok Kabupatenkabupaten adalah kekhasan kebudayaan masyarakat daerah setempat. Dalam prakteknya tidak semua masyarakat meninggalkan budaya asli setempat dan beralih kepada budaya modern dengan diikuti oleh perkembangan pesat di bidang teknologi sehingga keunikannya masih bisa dirasakan sekarang. Perkembangan dari strategi dalam menerjemahkan lingkungan itu membawa masyarakat untuk terus menerus mengkonstruksi pikirannya membangun budaya dan selanjutnya menjadi sebuah kebiasaan yang diturunkan secara berkelanjutan.

$$
\text { Penerjemahan budaya dari }
$$

lingkungan ini yang cenderung disebut 
dengan tradisi. Tradisi pada masyarakat tradisional tergantung dari sistem kepercayaan yang dianut oleh kelompok atau komunitas adat pendukung kebudayaan tersebut. Setiap kebudayaan memiliki tradisi yang beraneka ragam mulai daur hidup, ritual yang menyangkut ekonomi seperti ritual dalam pertanian, dalam arti luas termasuk perikanan, tradisi yang menyangkut sistem kepercayaan seperti nyale di Nusa Tenggara Timur dan juga dalam prosesi ritual sering pula dalam bentuk permainan-permainan (Suarsana 2014:3).

Tradisi nyale merupakan salah satu kearifan lokal di Kabupaten Sumba Barat. Tradisi tersebut mempunyai potensi wisata dan dianggap oleh masyarakat setempat memiliki nilai-nilai yang terkandung di dalamnya dan masih terpelihara sehingga menjadi salah satu daya tarik orang untuk menyaksikan ritual secara langsung. Menurut Yudi Hartono dan Dewi Setiana (2012: 54-55) Tradisi penting untuk dilestarikan dengan mengupayakan pelestariannya dalam dua faktor yaitu faktor intern menekankan pelestarian dalam masyarakat karena takut bila tradisi tidak dijalankan berdampak buruk bagi mereka, dan faktor ekstern terutama lembaga pemerintah daerah dalam mendukung kegiatan melestarikan budaya lokal. Seiring perkembangan tradisi Nyale dalam upacara Pasola yang telah dikenal oleh masyarakat lokal, nasional dan menarik wisatawan internasional, akan tetapi sebenarnya ada yang dilupakan bahkan pelaksanaannya semakin menghilangkan makna. Konteks makna dalam kajian budaya dipahami dalam konsep pragmatis aktifitas sehari-hari manusia, bukan persoalan yang dipahami sebagai peta makna yaitu yang dibagikan dan dipertandingkan. Ssehingga keterlibatan perhatian khusus yang ditunjukan kajian budaya dalam melihat dan mengeksplorasi tema budaya yang memberikan tekanan pada persinggungan antara kekuasaan dan makna (Wittgenstein, dalam Chris Barke 2014:167-169). Bentuk makna diperhitungkan sebagai istilah sebab. Bentuk ini mempunyai konsep dalam bidang ilmu tertentu yakni bidang linguistik. Menurut Kempson (dalam Mansoer Pateda, 2010: 79) terdapat tiga hal yang teah dijelaskan oleh filsuf dan linguis sehubungan dengan usaha menjelaskan istilah makna, yaitu a) makna sebagi kataalamiah, b). mendeskripsikan secara alamiah dan (c). apa yang didbutuhkan oleh pembicara untuk berkomunikasi. Hal yang sama dikemukakan oleh Palmer (dalam Mansoer Pateda, 2010: 96) mengemukana bahwa jenis makna dibagi menjadi beberapa hal, yaitu: a) makna kognitif, b) makna ideasiona, c) makna denotasi, dan d) makna 
proposisi.

Dari pandangan tersebut makna dipahami sebagai suatu kata yang memiliki nilai, unsur, manfaat dan kajian dalam peristiwa. Makna dalam kaitannya dengan hal ini mempunyai kesinambungan dengan kondisi dari tradisi Nyale. Nyale yang merupakan upacara yang dilakukan oleh raja, sesepuh, dan masyarakat Sumba Barat adalah upacara adat secara turun temurun dan dilaksanakan sebelum melakukan upacara Pasola. Upacara Pasola yang ditandai dengan pencarian cacing laut, tidak terlepas dari kepercayaan orang sumba yang belum menganut agama, namun upacara ini melibatkan semua orang Sumba untuk menonton pertunjukan pasola serta mengikuti ritual adat karena sama-sama meminta berkat kepada Tuhan Yang Maha kuasa untuk kesejahteraan daerahnya. Marapu yang dikenal sakral atau karismatik menjadi tonggak diadakannya upacara ini. Marapu merupakan kepercayaan terhadap rohroh berkekuatan gaib dan bagian dari upacara nyale dan pasola. Upacara tersebut dilakukan setiap bulan februari dan September.

Selanjutnya, keberadaan era globalisasi tentu membawa perubahan yang signifikan terhadap masyarakat yang majemuk terutama proses akulturasi yang mana terjadi pencampuran kebudayaan tetapi tidak menghilangkan budaya aslinya. Bahkan berkembangnya ilmu pengetahuan dan teknologi di era saat ini semakin mengurangi makna dan nilai dari kesakralan suatu tradisi yang dimiliki masyarakat adat (Fransiska Idaroyani Neonnub dan Novi Triana Habsari, 2018: 107). Namun kondisi tersebut tidak berlaku di daerah Sumba Barat Nusa Tenggara Timur yang warisan budaya lelulur masih eksis bahkan dikenal masyarakat luas sehingga setiap kali diadakan upacara ini partisipasi wisatawan yang berkunjung dan menyaksikan sendiri pertunjukan tersebut. Warisan leluhur ini nyatanya membawa banyak keuntungan dalam segi pariwisata dan tata kelola kota yang menarik perhatian para pengunjung. Tujuan penelitian ini adalah untuk mengetahui makna nyale dalam upacara adat Pasola sebagai upaya pelestarian budaya di Sumba Barat NTT.

\section{METODE PENELITIAN}

Metode yang di gunakan dalam penelitian ini adalah metode kualitatif. Penelitian kualitatif adalah penelitian yang menekankan sifat suatu barang atau jasa, berupa kejadian yaitu gejala sosial dibalik kejadian sebagai pelajaran berharga bagi pengembangan konsep teori berupa sumbanganya terhadap teori, praktis, kebijakan, masalahmasalah sosial dan tindakan (Berg dalam Dja 'man Satori dan Aan Komariah 2017: 
23). Teknik pengumpulan data dilakukan secara triangulasi, analisis data bersifat induktif/kualitatif, dan hasil penelitian kualitatif lebih menekannkan makna dari pada generalisasi (Sugiyono, 2013: 9). Pada dasarnya penelitian kualitatif digunakan dalam penelitian yang merujuk pada objek dan fenomena alami. Jenis penelitian menggunakan deskriptif analitik yakni membangun pola pikir dengan cara bertolak dari halhal umum, dari pengetahuan, teori, hukum yang membentuk proposisi dalam silogisme. Penelitian dilaksanakan dengan menganalisis data yang di peroleh dari wawancara, dokumentasi, dan observasi langsung di lapangan. Sumber data yang digunakan adalah Data Primer berupa wawancara dengan informan yaitu tetua adat yang dianggap mengetahui upacara mencari cacing laut dan pelaksanaan prosesi pasola. Sumber data sekunder diperoleh dari bahan pustaka. Teknik analisis data yang digunakan adalah a). Reduksi data yang ditulis dalam bentuk laporan atau data terperinci. Laporan disusun berdasarkan data yang diperoleh direduksi dirangkum, dipilih hal-hal yang pokok, difokuskan pada hal-hal yang penting, b). Penyajian data dilakukan dalam berbagai bentuk seperti tabel, grafik dan sejenisnnya. Penyajian data dapat dilakukan dalam bentuk uraian singkat, bagan, hubungan antar kategori dan sejenisnya. Dengan demikian yang paling sering digunakan untuk menyajikan data adalah teks naratif, c). Penarikan kesimpulan dari hasil penelitian.

\section{HASIL DAN PEMBAHASAN}

Sejarah Tradisi Nyale

Kabupaten Sumba Barat adalah salah satu Kabupaten yang ada di Propinsi Nusa Tenggara Timur yang memiliki semboyan Pada Eweta Manda Elu yang artinya padang hijau, tanah yang subur. Wilayah Kabupaten Sumba Barat daerahnya kering, berbukit-bukit, sedikit lembah-lembah datar yang digunakan untuk usaha perkebunan, pertanian dan peternakan. Keadaan alam, kehidupan sosial dan hubungan kekerabatan yang ada di pulau ini kini terus di jaga eksistensi budayanya. Orang sumba beranggapan bahwa pulau mereka sanga sakral dan pandangan orang sendiri pada pulau ini mengandung sangat mistis berkaitan dengan kepercayaan asli orang Sumba yaitu kepercayaan marapu. Pada pasca kolonialisme banyak peninggalanpeninggalan yang di rasakan, di alami, dan di amati di pulau Sumba. Orang Sumba menyebut pulau mereka sendiri adalah tanah humba, tanah Sumba, tau humba atau orang Sumba. Sekalipun berbeda bahasa, pakaian adat, lagu daerah, makanan khas akan tetapi kehidupan sosial dan hubungan kekerabatan dan adat istiadat maupun kepercayaan orang Sumba itu sama. 
Belis atau mahar bagi perempuan Sumba sangat di takuti oleh lelaki karena untuk mendapatkan seorang perempuan Sumba harus berkorban. Berkorban hewan yang diberikan kepada keluarga perempuan. Jika dahulu kala ibunya di belis 50 ekor hewan kuda, maka anak perempuannya juga harus 50 ekor kuda dan alangkah baiknya juga harus lebih. Jika tidak maka akan terkena denda adat, dan keluarga lakilaki tidak akan dianggap dan di hina bahwa tak mampu untuk membayar belis. Alat dan bahan belis atau mahar antara lain: kuda, kerbau, mamoli (sejenis alat kelamin wanita yang di ukir) dan tongkat seperti yang di gunakan dalam Pasola. Orang yang meninggal seperti raja, memiliki hewan banyak, dipandang dan dikenal banyak orang apabila meninggal akan di kuburkan menggunakan batu besar (megalithikhum) sekalipun sudah masuk Gereja. Penyembelihan hewan juga dilakukan untuk memberi makan pada nenek moyang melalui upacara sesaji misalnya dalam upacara kematian, penjemputan perempuan, upacara panen raya, upacara kelahiran, upacara peletakan batu pertama.

Masih banyak upacara-upacara adat yang akan dilaksanakan. Upacara demikian itu sebenarnya untuk menghargai leluhur yang sudah meninggalkan budaya kepada generasi sekarang. Semua itu tidak terlepas dari budaya, adat, dan tradisi Orang Sumba termasuk ritual Nyale dan upacara Pasola untuk menghormati kemuliaan leluhur yang sudah di selamatkan oleh marapu. Nyale adalah upacara mencari cacing laut yang dilaksanakan pada sore hari di pinggiran pantai yang di pimpin oleh rato atau tua adat. Tradisi ini merupakan salah satu warisan kebudayaan yang memilki makna yang sangat penting bagi masyarakat Sumba Barat yang di percayai dan sangat di agungkan sejak ratusan tahun yang lalu yang di wariskan oleh para leluluhur dan masih bertahan sampai saat ini. Nyale memiliki sejarah yang mana pada zaman dulu kala ada cerita mengenai kisah perebutan cinta antara pria Sumba Barat Daya dan wanita dari Sumba Barat yang tidak disetujui oleh kedua orang tua dan pria tersebut nekat untuk membelis perempuan tadi dengan 100 ekor kuda karena pihak keluarga menuntut agar perempuan ini di kembalikan maka pihak keluarga pria menyediakan cacing laut dan pasola untuk memeriahkan kembalinya perempuan ke rumah asalnya ke kampung waiwuangan yang mana kampung pasola di laksanakan pertama di tempat itu. Dari sejarahnya tersebut memunculkan filosofis bagi masyarakat Sumba Barat bahwa nyale merupakan anugerah dari Tuhan sehingga prosesi ini nampaknya sakral dan di percayai oleh masyakat setempat. 
Dari data di atas juga di dukung oleh Charles Weru (Kepala kecamatan Wanokaka) yang memaparkan bahwa Pasola wanokaka secara budaya adalah budaya yang datang dari kodi dan kegiatan itu merupakan penggganti belis antara kabisu atau marga di kodi yaitu kabisu bitosi oleh karena perkawinan yang putus oleh karena da istri bangsawan orang Wanokaka yang namaya adalah Rabu Kabba yang di bawa lari atau di nikahi sembunyi oleh Teda Gaiparona. Ketika perkawinan adat di laksanakan ganti belis itu semua di gantirugikan oleh pihak laki-laki dari kodi berupa hewan-hewan yaitu kerbau, kuda, dan parang serta mamuli emas dan sebagainya. Akan tetapi waktu mereka mau pulang, keluarga dari pihak perempuan kembali ke Wanokaka, mereka dalam hal ini pihak dari kaum laki-laki menuntut untuk memberikan makanan berupa Nyale tetapi orang Kodi di Sumba Barat Daya tidak menyetujui tetapi Orang-orang atau pihak keluarga perempuan terutama dari kabisu Waiwuang yaitu tempat asal Umbu Dulla sebagai suami dari Rabu Kabba. Oleh karena ketidaksetujuan tersebut, pihak keluarga dari Wanokaka menuntut agar nyale dibawa ke Wanokaka tetapi ada permintaan mereka untuk merayakan dalam bentuk Pasola. Maka mulai dari saat itu Nyale dibawa ke Wanokaka dan setiap bulan Maret dilaksanakan oleh kabisu Waiwuang Kecamatan Wanokaka.

\section{Prosesi Pelaksanaan Nyale}

Pada bulan Februari atau September dalam rangkaian kalender adat para rato diseluruh Kecamatan Wanukaka mulai menghitung hari, dan posisi atau letak bulan dimana maka akan ada penetapan waktu pelaksanaan pencarian nyale. Ketua rato mulai mengadakan rapat atau undangan kepada seluruh jajaran di rumah adat atau perkampungan dengan tujuan utama untuk menetapkan bersama hari apa yang tepat untuk melaksanakan Nyale dan Pasola. Dalam perbincangan tersebut mulailah mereka berdiskusi dan mencari satu solusi yang tepat jika ada yang setuju atau tidak. Jika sudah disepakati hari apa pelaksanannnya maka mereka menyembelih ayam, babi, sebanyak mungkin untuk melihat rahmat yang apakah diijinKan oleh leluhur atau tidak. Mulailah mereka secara bergiliran melihat hati aam dan usus ayam bahwa disitu terdapat petunjuk dari Tuhan, dengan sendirinya para rato akan tau karena mereka memperoleh ilham untuk menafsirkan dari setiap hati ayam atau usus ayam maupun babi. Jika hasil tafsiran yang baik maka upacara tersebut siap untuk dilakukan. Bagi orang Sumba pada umumnya yang memiliki kepercayaan marapu hati ayam, usus ayam,dan hati babi merupakan kitab bagi mereka dalam melihat hal-hal yang terjadi baik kehidupan masyarakatnya, kematian, 
tanda-tanda bahaya, tanda keberuntungan lewat upacara sesajian. Setelah upacara sesajian telah dilaksanakan maka para ratoakan mengumumkan kepada masyaraktnya bahwa pelaksanaan pencarian nyale sudah dekat pada hari sekian tanggal sekian dan pasolanya juga demikian. Setelah itu para rato akan di panggil ke kecamatan menghadap bapak Camat untuk mendengar arahan sekaligus pemberian Sirih Pinang unuk kelancaran upacara tersebut sebagai bentuk dukungan dari mereka juga akan disembelih sapi untuk makan bersama bagi parapenonton atau keluarga pengunjung.

Pada sore hari menjelang jam 4 sore sampai subuh, masyarakat berbondong bondong di pimpin oleh rato untuk mengambil nyaledi pesisir pantai Wanukaka. Nyale yang di tangkap baik dan banyak maka menandakan hasil panen tahun ini baik. Jika Nyale itu menggigit tangan rato hancur maka hasil panen tahun ini mendapatkan musibah yang tidak menguntungkan pada hasil panen yaitu padi di gigit tikus. Sebelum tiga hari pasola maka akan adakan tinju adat atau pajurra dan tidak mengunakan kelengkapan apapun dan esok harinya akanada tes arena dan tes kuda untuk menuju pasola. Kelengkapan mencari cacing laut menggunakan kaleku (bakul) yang dianyam dari daun pandan. Merujuk pada hasil wawancara
Adorina Podu Goli (masyarakat dipesisir pantai wanukaka) bahwa budaya yang masih di pertahankan sampai saat ini masih di lestarikan keberadaannya, yang walaupun masyarakat Sumba Barat sudah mengenal agama yaitu Kristen tidak menuntut kemungkinan untuk tidak melaksanaan ritual tersebut. Tokoh-tokoh adat salah satunya rato sebagai pelaku utama dalam kegiatan tersebut sangat antusias agar peninggalan produk sejarah ini tetap di laksanakan. Berkembangnya teknologi nyatanya warisan ini sudah melupakan larangan-larangan atau aturan yang seharusnya tidak di hilangkan.

Selain itu, Kepala Dinas pariwisata Kabupaten Sumba Barat menjelaskan bahwa Tradisi nyale sebenarnya memiliki makna yang penting bagi masyarakat. Dari masyarakat sendiri pada waktu pelaksanaan sangat bangga sebab bukan hanya keramaian tetapi prosesi pelaksanaannya itu yang sangat sakral karena budaya ini hanya ada di Sumba tidak ada di tempat lain. Meskipun mendapat pengaruh dari perkembangan ilmu pengetahuan dan teknologi dan masuknya budaya dari luar tetapi orang Sumba Barat sendiri tetap mempertahankan warisan ini. Tentu dari segi luar biasanya begitu para rato sudah menghitung hari, minggu, dan bulan serta kalender adat maka para undangan dari keluarga masing-masing 
msayarakat Sumba Barat mereka sudah datang untuk menyaksiskan langsung tetapi dengan gaya mereka sendiri misalnya dalam berpakaian, seharusnya pakaian adat mereka datang dengan pakaian bebas.

Sebelum ritual penangkapan Nyale pertama harus menunggu dulu dari rato semua sebelum pagi hari. Selanjutnya rato memanggil dengan sebutan wuuuuuuuu wuuuuu (panggilan kepada Nyale) dengan sendirinya Nyale akan datang. Kata wuuuu berarti memanggil kawan rato juga sekalian Nyale. Jika Raja pertama yang naik di atas batu dan berteriak wu wu wu dan Nyale tidak muncul maka akan saling menuding.

\section{Persiapan dalam pencarian Nyale}

Dalam rangka datangnya bulan Nyale di Wanokaka selama memasuki bulan pencarian cacing laut itu tidak boleh ada bunyi-bunyian dalam bentuk appun baik yang menangis, bunyi gong, giring-giring, teriakan khas Sumba tidak di perbolehan, kemudian tidak diperbolehkan untuk melangsungkan perkawinan, jika ada ang meninggal tidak di perbolehkan untuk menangis, tidak diperbolehkan menagih hutang walaupun ada yang punya hutang di tetangga terdekat. Setelah masuknya pencarian nyale ada penyucian benda keramat setelah itu dilaksanakan lagi sembahyang keliling di daerah Wanokaka. Ketika tinggal tersisa satu hari pelaksanaan Pasola maka rato di Ubu Bewi akan menyampaikan sembayang dan memohon kepada marapu sebagai berikut

"hadirkanlah nyale besok, biarkanlah kami bertemu banyak dan utuh serta tidak rusak. la meminta yang menghuni langit dan yang berada di bumi bawalah nyale di tepi pantai untuk kami bisa makan secara bersama-sama kami menikmati karena disanalah kai dapat mengetahui siklus kehidupan kami di bidang pertanian".

\section{Pelaksanaan pencarian nyale dan} pasola sudah dimulai jika rato dari Waiwuang sudah menurunkan larangan di laut dengan membuang sirih pinang maka masyarakat dengan sendirinya harus tau, bila rato sudah buang larangan berarti kita tidak boleh untuk melaut, memakai baju merah. Hal tersebut juga dijelaskan oleh Mawu Happu (pemeran utama yang bertugas dalam ritual) bahwa dari jauh hari perhitungan waktu pasola oleh rato itu, mereka pakai batu sebanyak dua belas batu, masuk bulan pertama batu itu rato kasi pindah, masuk bulan kedua rato kasih pindah lagi sampai hari $\mathrm{H}$ pelaksanaan pasola ini. Setelah bulan pasola sudah tiba maka rato sudah naik di atas batu dan memantau seluruh isi pesisir pantai maka dengan sendirinya rato akan omong ai ini nyale sudah datang ini kita sudah harus siap-siap, dia punya tanda-tanda sudah tampak dari jauh dari dalam laut. Nanti rato sudah 
naik ke darat dia akan kumpulkan semua rato-rato dari satu kecamatan untuk bicarakan soal penempatan harinya kapan, dalam penempatan harinya kapan itu tidak boleh salah karena nanti dampaknya di nyale itu dia tidak naik karena salah pilih hari. Setelah ritual nyale dan pasola diaksanakan di rumah adat tidak saja berhenti di tempat itu, nanti di pimpin oeh rato bersama ibuibu membawa pisang, makanan di mbuala mangejing atau di bakul besar dan sampai di pantai itu mulailah rato pertama sebagai inti untuk menyembelih ayam sebanyak-banyaknya untuk melihat izin dari leluhur, selain itu membakar pisang demi gunanya untuk melanjutkan ritual itu, makan bersama.

Madidi nyale (Memanggil Nyale) Ritual yang secara harafiah berarti memanggil Nyale ini berlangsung di pantai Wanukaka pada hari ke empat. Ritual di mulai dengan sesaat seelum fajar setelah rombongan rato selesai melakukan ritual di Ubu Bewi da beriringan menuju pantai untuk memimpin upacara. Warga dan wisatawan ikut berburu Nyale. Cacing laut yang berwarna-warni yang selain sedap di jadikan kudapan juga menjadi indikator hasil panen. Nyale yang banyak dan bersih berarti panen melimpah sebaliknya Nyale kotor dan menggigit berarti ada hama tikus. Selain itu, Nyale busuk berarti padi menandakan busuk, sebaliknya Nyale tidak muncul berarti menyebabkan kelaparan.

Pasola

Awalnya pasola ini dilaksanakan hanya di daerah Waiwuang atas dan Waiwuang bawah akan tetapi karena tidak rame lagi mereka minta lagi sukusuku yang lain untuk terlibat terutama suku Praigoli namun pelaksanaannya tidak rame, kemudian inisiatif sesepuh meminta suku Lahimajera namun hal yang sama tidak rame juga, dan tibalah pada suku yang ketiga adalah suku Praigoli namun suku ini terjadi perang suku Praigoli dimana para rato-rato penyelenggara Pasola itu sendiri di bunuh oleh kabisu dari Lamboya yaitu kecamatan yang bersebelahan dengan Wanokaka. Maka berangkat dari situ untuk menjalani keamanan dan ketertiban maka Pasola yang di selenggarakan di Wanokaka bawah di minta lagi kepada raja Waigali di Wanukaka karena di jamin dapat menjaga kegiata ini karena ia juga sebagai Raja di Praigali yang sampa sekarang terus di lakukan di Praigali bersebelahan dengan Sekolah Dasar. Jadi inti pelaksanaan ritual Pasola adalah menyambut kedatangan Nyale. Dalam pasola biar ada yang meninggal tidak ada sanksi, darahnya bercucuran tidak ada sanksi, jika meninggal maka orang atau pihak lawan akan akan membawa kain dan tidak ada tuntutan 
secara adat dan hukum karena berpikir secara adat, tradisi dan budaya begitu pula tuntutan dari keluarga tidak ada. Dulu di anjurkan untuk memakai kain hitam dalam menangkap nyale. Jika menjelang bulan pasola pemerintah sendiri memanggil para rato di Kecamatan untuk pelaksanaan ritual nyale. Semakin masyarakat dan rato inti mengenal Gereja dengan sendirinya pelaksanaan ritual tidak terlalu di laksanakan contohnya laranganlarangan. Nilai sebuah budaya sudah terganggu. Tidak menekan lagi larangan-larangan itu harus di taati. Walaupun rato sudah mengenal Gereja tidak menuntut keungkinan untuk tidak ikut harus wajib tetapi rato yang utama itu adalah dia yang berperan. Para rato juga mnyediakan rumah dan pelengkap ritual untuk pelaksanaan karena la sebagi senior atau orang yang berpengalaman. Tahapan pelaksanaan diadakan lagi upacara atau ritual yaitu manyautung atau syair adat bersahutsahutan antar semua rato, sebelumnya harus ada kuda yang memilki leli wihis (giring-giring yang di ikat pada kaki kuda) untuk pertama masuk kelapangan maka semua kuda yang lain menyusul dalam lapangan pasola.

Sebelum lahirya Pasola itu ada yang namanya Nyale. Nyale adalah sebuah cacing wawo yang ada di pantai yang biasa muncul setiap tahun sekali. Kebrmunculannya itu pas pada bulan
Februari. Pencarian Nyale itu biasanya pada bulan purnama, dalam bulan purnama ini para rato atau tokoh adat dan masyarakat Sumba Barat semacam ada inspirasi bahwa pada bulan Februari itu ada sebuah berkat yang sangat berlimpah yang akan datang untuk masyarakat disana. Sehingga pada malam harinya itu mereka berbondongbondong dari sore sampai malam menggunakan lampu seadanya saja yaitu lampu sulu atau lampu obor. untuk menghargai tanda syukuran itu pertama kali ada istilah yang namanya pajurra atau tinju tradisional Sumba Barat dengan tidak menggunakan apa-apa hanya dengan kepalan tangan kosong, karena itu sebagai wujud kegembiraan mereka dalam panen Nyale. Kemudian muncul lagi dari kalangan muda yang melarikan kuda di pinggir pantai dengan menggunakan lembing atau tombak maka dari situ muncullah inspirasiinspirasi dari tua-tua adat atau rato-rato maupun sesepuh untuk tidak berkelahi begitu saja dan akhirnya membagi kegiatan Pasola diberbagai wilayah. Kayu pasola yang di gunakan pada saat ini bukan kayu yang di gunakan biasa itu saja, pada zaman dulu leluhur itu menggunakan rumput semacam alang dalam bahasa Lolinya itu adalah Nalo, dan dalam bahasa Anakalang ataupun Wanokaka di sebut wua hola yang terdiri atas kayu ringan yang mudah patah, dan berkembang dari wua hola akhirnya 
mereka menggunakan kayu, kayu juga yang di gunakan pada saat ini bukan kayu yang seperti sekarang, pada masa dulu itu menggunakan kayu yang tumpul ukuranya juga tidak boleh menggunakan kayu yang besar.

Akan tetapi dalam perekembangan-perkembangan terus kini msyarakat Wanokaka menggunakan kayu yang sekarang ini. Pasola itu adalah tanda syukur mereka kepada alam yang memberi mereka berkat, memberi mereka pengetahuan dan seterusnya sehingga lahirlah Pasola yang di lakukan hingga saat ini. Istilah Pasola sampai saat ini sudah di modifikasi oleh masyarakat karena tingkat pengetahuan, peradaban, karena perkembangan jaman sesuai dengan perkembangan kehidupan masyarakat juga dengan tigkat pengetahuan masyarakat Sumba Barat kususnya Kecamatan Wanokaka. Walaupun banyak versi dari pengertian dan penjelasan mengenai pasola, akan tetapi sebenarnya kesimpulan akhirnya adalah Pasola adalah tahun baru suku Wanokaka, suku Lamboya, suku Kodi dan suku Gaura sehingga pada bulan Februari itu adalah bulan kehidupan bagi mastyakat Sumba Barat yaitu tahun baru kalender adat umumnya Sumba dan kususnya mereka yang melaksanakan kegiatan tersebut dari berbagai suku tersebut.

\section{Perlengkapan Pasola}

Terkait dengan budaya Sumba, perlengkapan untuk orang Pasola juga bawaan dari kepada leluhur orang Sumba yang kita sebut rato-rato atau tokoh adat atau sesepuh mereka yang mempunyai karismatik untuk melaksanakan suatu kegiatan. Pakaian mereka yaitu menggunakan pakaian tenunan semacam kain kemudian balutan atas bawah lengkap dengan ikat kepala itu merupakan simbol pahlawan yang mereka gunakan. Orang yang masuk di dalam lokasi Pasola itu merupakan orang yang betul berani bertanggung jawab untuk dirinya sendiri walaupun nanti akan berhadapan dengan maut sekalipun, jadi lambanglambang kepahlawan itu diekspresikan dalam cara berpakaian mereka. Selain itu ketangkasan pria Sumba Barat, mereka menggunakan parang asli Sumba yang diselipkan pada pinggang. Parang itu juga yang bagus, misalnya pegangannya dari tanduk kerbau yang di ukir untuk meletakkan isi parang atau pemotongnya ke dalam tanduk tersebut dan diperuntukan bagi mereka yang masuk dalam lapangan Pasola.

Lembing atau kayu atau wua hola sebagai pelengkap bagi kaum lakilaki atau kaum pria Sumba Barat namun bagi rato-rato seperti itu juga mereka lengkap dengan atribut-atributnya namun ada yang beda, dengan yang di lapangan permainan Pasola. Rato menggunakan tabelo, maraga, mamuli, 
dan semua itu berasal dari bahan emas, dalam pelaksanaan Pasolamereka wajib menggunakan itu sebagai simbol-simbol atau tanda pengenal bahwa mereka adalah rato. Selain kaum pria Sumba yang memakai kain, dan demikian pula rato, ada juga kaum perempuan Sumba Barat yang memiliki peran penting yang memakai sarung khas Sumba atau lawu. Di tangan mereka di hiasi gelang tangan yang terbuat dari gading. Ada juga hiasan di telinga yaitu emas dan ada yang mereka gunakan di kepala dan di testa. Barang tersebut setiap tahun harus disucikan pada bulan masa Pasola tersebut. Di sucikan itu bukan digunakan dengan ritual biasa dengan air biasa, tetapi ritual penyembelihan hewan kurban yaitu babi. Tujuannya untuk disakralkan atau dikeramatkan. Barang itu jika dicuri biasanya akan hilang ditempatnya, sebab sudah disakralkan dengan air berkat yang sudah di doakan oleh rato melalui penyembahanpenyembahan hewan kurban bagi leluhur.

\section{Tata aturan dalam pasola}

Biasanya tata aturan dalam Pasola itu ada panitia atau tim yaitu rato-rato atau tokoh adat. Biasanya rato dari Waiwuang, Ubu Bewe, Wai Gali yang menjadi penjuru. Jadi tidak ada intervensi dari Pemerintah atau pihak keamanan. Adapun peraturannya adalah mereka dalam hal ini rato sudah menyampaikan kepada seluruh pemain
Pasola untuk tidak boleh melakukan tindakan kriminal atau niat jahat, tidak boleh ada dendam dan tidak boleh menggunakan barang-barang seperti memotong orang dengan parang, melempar dengan batu, dan mereka menggunakan kayu Pasola. Apabila ada yang melanggar peraturan maka dengan akan diserahkan kepada pemerintah bahwa orang tersebut sudah menyimpang dari apa yang menjadi budaya, keyakinan atau kepercayaan orang Sumba, khususnya bagi yang melaksanakan upacara tersebut. Kegiatan ini juga sudah berlangsung dari tahun ke tahun tidak ada juga campur tangan dari pihak manapun.

\section{Nilai-Nilai Yang Terkandung Dalam Upacara Pasola}

Pasola merupakan sebuah ritual yang diselenggarakan berkenaan dengan perayaan adat pasca panen. Pada saat inilah masyarakat melakukan serangkaian upacara adat yang pada prinsipnya bertujuan untuk mengungkapkan rasa syukur terhadap alam semesta. Waktu pelaksanaan pasola dilaksanakan setahun sekali, namun pelaksanaannya tidak menggunakan kalender masehi, namun berdasarkan perhitungan bulan purnama yang terbit setiap malam. Keputusan pelaksanaan ritual adat ditentukan oleh seorang rato atau imam dari suatu kampung adat. Untuk ritual pasola sendiri biasanya dilaksanakan setiap 
awal bulan Februari, akan tetapi perhitungan menentukan tanggal pasola dihitung mulai dari munculnya bulan purnama dan setelah itu acara pelaksanaan pasola akan ditentukan oleh rato. Rato merupakan orang penting dalam hal menentukan tanggal pelaksanaan pasola. Budaya yang kental dan pertimbangan rato inilah yang membuat jadwal pasola terkadang bisa berubah. Tetapi mereka sudah menentukan kapan tanggal dan hari yang tepat untuk melaksanakan pasola tersebut, baru setelah itu pemerintah daerah menetapkan kapan pasola akan diadakan.

Sampai tahun ini pelaksanaan tradisi Pasola tetap berlangsung dalam agenda tahunan dan menjadi festival guna promosi pariwisata yang oleh pemerintah Kabupaten setempat, yakni pemerintah Kabupaten Sumba Barat untuk pasola di Lamboya, Wanukaka, dan Gaura. Sedangkan di Kabupaten Sumba Barat Daya, dikawasan Kodi ada lima tempat: Homba Kalayo, Bondo Kawango, Rara Winyo, Waiha, dan Wainyapu. yang jatuh pada bulan sama yaitu antara Februari-Maret (Suarsana dkk, 2017: 52-83). Menurut Carles (Tokoh pemerhati budaya) berdasarkan kerangka kepercayaan orang Sumba Nyale terdapat beberapa nilai diantaranya adalah

1. Nilai historis berkaitan dengan sejarah kedatangan nyale dari kodi karena dalam silsilahnya menceritakan antara cinta segitiga.

2. Nilai simbolik berkaitan mana kala dikatakan saat Pasola di Wanokaka berlangsung misalnya, ada Nyale yang menggigit tangan rato tandanya ada tikus pada musim panen yang akan datang. Selain itu ada Nyale busuk maka akan ada tanda bahwa air atau hujan itu terlampau banyak dan akan mengancam tanaman padi.

3. Nilai Religius berhubungan dengan kepercayaan asli orang Sumba pada umumnya dan khususnya yang melakukan ritual tersebut. Kepercayaan itu adalah marapu yang di sembah saat ini adalah masyarakat adat tersebut. Masyarakat sebagai penyelenggara ritual dan bagian sistem kepercayaan bahwa nyale yang hadir di bulan Maret adalah seperti kiriman dari Yang Maha Kuasa dan dianggap sebagai tubuh dewa. Oleh karena itu makna nyale yang dalam Pasola sangat dihormati dengan cara sembayang atau berdoa dalam bahasa adat. Nyale menjadi sangat penting dalam siklus kehidupan orang Sumba yang pekerjaannya sebagai petani sawah di Wanokaka.

4. Nilai pesaudaraan. Mereka boleh bermusuhan dilapangan ibaratnya sama dengan permainan sepak bola saling mencari yang kalah dan menang tetapi tujuaannya adalah 
rasa persaudaraan. Sebab permainan itu hanya berkaitan dengan menghargai budaya leluhur orang Sumba.

5. Nilai kepahlawanan, artinya Orang Sumba mempunyai jiwa patriotisme dan pahlawan. Contohnya ketika dilapangan maka sebagai ksatria besar yang tidak akan mendendam lawan. Masalah di lapangan dan tempat Pasola diselesaikan selama pelaksanaan kegiatan Pasola.

6. Nilai sosial budaya, yaitu gotong royong bekerja sama untuk mensukseskan kegiatan mulai dari ritual sebelum mencari cacing laut atau nyale sampai tahap pelaksanaan Pasola hingga selesai. Gotong-royong tersebut adalah dari seluruh penjuru Sumba yang ikut menyaksikan langsung kegiatan Pasola melalui bertamu. Misalnya, tamu yang datang berkunjung dari Sumba Timur maka di tempat pelaksanaan Pasola disiapkan makan, menyembelih babi, anjing, dan kerbau untuk makan bersama-sama.

7. Nilai ekonomi. Apabila pengunjung mempunyai keluarga di tempat Pasola maka harus membawa kain sarung atau selimut. Bila perlu juga memberikan babi kepada keluarga tempat kita nginap atau tidur dan keluarga tersebut menjamu kita dengan balasan kameti seperti pertukaran barang dengan barang (barter). Selain itu, ada nilai silahturahmi, yaitu melalui ritual pelaksanaan kegiatan tersebut, seluruh yang memiliki keluarga, sahabat, kenalan termasuk masyarakt Sumba Barat Kecamatan Wanokaka hanya bisa bertemu di tempat itu setahun sekali.

\section{Upaya Pelestrian Budaya}

Makna budaya sebagai orang Sumba yaitu bahwa nilai-nilai budaya di Sumba hanya ada di Sumba seperti ritual Nyale, upacara Pasola, rumah adat budaya Sumba, kampung-kampung tadisional seperti rumah adat Praiijing di Wanokaka, dan juga terdapat potensi bahari yang begitu unik. Orang Sumba pada umumnya seperti di depan rumah adat atau rumah perkampungan mereka terdapat batu kubur atau batu besar (megalitikhum) di halaman rumah untuk menghagai arwah yang sudah meninggal. Harapannya adalah Sumba makin dikenal melalui penelitian yang ingin mendalami mengenai pulau Sumba sehingga dapat memperkenalkan Sumba di dunia luar karena sejauh ini masih banyak budaya yang belum dipublikasikan. Orang sumba sendiri untuk kaum muda harus mencontoh apa yang dibuat oleh pemangku adat atau budaya. Setiap kegiatan harus diketahui maknanya, misalnya tarian kabokang maknanya apa atau tarian kataga maknanya apa. Bekerja meningkatkan ekonomi masyarakat lewat budaya dan 
juga melalui kegiatan nyata. Kearifan lokal ini harus di jaga eksistensinya misalnya Pasola dengan menjaga dan melestarikan makna dari setiap pelaksanaannya harus dipahami sehingga dalam upacara tersebut tidak ada anggapan bahwa ajang pertumpahan darah, ajang untuk balas dendam atau ajang permusuhan. Upaya pelestarian Nyale dan Pasola di Sumba Barat di Kecamatan Wanokaka sejauh ini terus dilaksanakan dan pemerintah memberikan perlindungan terhadap masyarakat berkepercayaan marapu sebagau penyelenggara dari ritual Pasola dan Nyale. Selain itu, memberikan rasa nyaman bagi masyarakat penganut Marapu untuk tidak diganggu oleh pihak-pihak lain karena mereka adalah pihak minoritas. Dukungan pemerintah daerah lewat bantuan dana pelaksanaan Pasola yang di berikan kepada para pemain pasola dan juga dukungan bagi para rato dalam bentuk sirih pinang itu berlaku setiap tahun di berikan bantuan.

\section{PENUTUP}

\section{Simpulan}

$$
\text { Nyale dalam sejarahnya }
$$

menceritakan tentang kisah perebutan cinta antara pria Sumba Barat Daya dan wanita dari Sumba Barat yang tidak di setujui oleh orang tua perempuan dan pihak keluarga menuntut agar perempuan ini dikembalikan, maka pihak keluarga pria menyediakan cacing laut dan Pasola untuk memeriahkan kembalinya perempuan ke rumah asalnya ke Kampung Waiwuang. Dari sejarahnya tersebut memunculkan filosofis bagi masyarakat Sumba Barat bahwa nyale merupakan anugerah Tuhan sehingga prosesi ini nampak sakral dan dipercayai oleh masyarakat setempat.

Makna upacara ini dilaksanakan sebagai tonggak utama menghargai peninggalan leluhur yang masih bertahan. Pelaksanaan prosesi tidak terlepas dari segi religi atau kepercayaan asli tau humba atau orang Sumba yaitu marapu. Syair adat dan upacara penyajian kepada roh-roh halus difungsikan sebagai naluri manusia dalam penerapan kepercayaan dan rasa Syukur Kepada Tuhan Yang Maha Esa yang di wujudkan dalam bentuk tradisi dan rangkaian proses ritual Nyale yaitu mencari cacing laut dan Pasola sebagai permainan perang-perangan $\mathrm{di}$ atas kuda menggunakan lembing atau tombak. Peranan ritual Nyale dan adat Pasola di Sumba Barat di maknai pula sebagai alat pemersatu masyarakat yang dalam pelaksanaan upacara ini sebagai bentuk jalinan persaudaraan sejati, sebagai bentuk ungkapan kegembiraan sejati dalam menyambut hasil panen yang baik. Walaupun upacara pasola dimaknai dengan ketakutan karena melukai lawan akan tetapi upacara ini terus dilestarikan eksistensinya. Secara 
garis besar Nyale dan Pasola sangat berkaitan erat dengan nilai-nilai luhur yang terkandung baik dalam tahap pelaksanaan, prosesi, laranganlarangan, dan kepercayaan yang dianut masyarakat Sumba. Adapun tahap-tahap dalam upacara Nyale dan Pasola adalah penentuan waktu dalam pencarian cacing laut mulai dari perkumpulan para rato, persiapan kelengkapan Pasola yaitu kayu lembing, kuda, kain adat, dan yang terakhir adalah prosesi pelaksanaan Pasola

Saran

Diharapkan pengelolaan wisata tradisi tersebut sebaiknya di muat dalam berita, surat kabar, dan media lain agar lebih diketahui oleh masyarakat luas. Pemerintah Daerah sebaiknya tentang tata kelola Kota sudah mestinya untuk dikelola lebih baik keberadaanya karena pengunjung dari luar semakin ramai, tentu akan menambah pemasukan serta pajak disetiap penginapan dan bisa dirasakan langsung oleh masyarakat setempat. Bagi masyarakat Sumba Barat, karena ini merupakan peninggalan leluhur maka tentu dijaga jangan sampai dilupakan setiap tahapan proses serta larangannya.

\section{DAFTAR PUSTAKA}

Chris Barker. 2014. Kamus Kajian Budaya. Yogyakarta. Kanisius

Djam'an Satory Dan Aan Komariah. 2017. Metodologi Penelitian Kualitatif. Bandung: CV. Alfabeta.
Fransiska Idaroyani Neonnub Dan Novi Triana Habsari. 2018. Belis: Tradisi Perkawinan Masyarakat Insana Kabupaten Timor Tengah Utara (Kajian Historis Dan Budaya Tahun 2000-2017). Agastya: Jurnal Sejarah Dan Pembelajarannya. Volume 8 Nomor 01 Tahun 2018: 107-126

I Made Suarsana, I Gusti Ngurah Jayanto, Dan I Kadek Dwi Kayana. 2014. Pasola: Di Sumba Barat Daya Nusa Tenggara Timur. Yogyakarta: Ombak

Khoirul Huda. 2017. Pengembangan Media Pembelajaran Ips Sejarah Melalui Aplikasi Sway Berkonten Indis Di Smp Negeri 8 Madiun. Historia: Jurnal Pembelajaran Sejarah Dan Kajian Sejarah. Volume 5 Nomor 2 Tahun 2017: 125-141.

Mansoer Pateda. 2010. Semantic Leksikal: Edisi Kedua. Jakarta: Rineka Cipta.

Safril Mubah. 2011. Strategi Meningkatkan Daya Tahan Budaya Lokal Dalam Menghadapi Arus Globalisasi. (Online). Dalam Http: / /Www.Journal.Unair.Ac.Id /Filerpdf /03\%20safril\%20strategi \%20meningkatkan\%20daya\%20tah an\%20budaya\%20lokal\%20safril\%2 Omda.Pdf. Diakses 18 April 2018 Pukul 22.53.

Sugiyono. 2013. Metode Penelitian Kuantitatif, Kualitatif Dan R\&D. Bandung: Alfabeta

Yudi Hartono Dan Dewi Setiana. 2012. Kearifan Lokal Tradisi Uyen Sapi Perajut Integrasi Sosial (Studi Kasus Di Desa Jonggol Kecamatan Jambon Kabupaten Ponorogo). Agastya: Jurnal Sejarah Dan Pembelajarannya. Volume 2 Nomor 1 Tahun 2012: 52-65. 
Makna Nyale dalam Upacara Adat Pasola..., Wilhelmus Kuara Jangga Uma dkk, 347-364 